\title{
Effects of wastewater treatment plant effluent inputs on planktonic metabolic rates and microbial community composition in the Baltic Sea
}

\author{
Raquel Vaquer-Sunyer ${ }^{1}$, Heather E. Reader ${ }^{2}$, Saraladevi Muthusamy ${ }^{3}$, Markus V. Lindh ${ }^{3, \text { a }}$, Jarone Pinhassi ${ }^{3}$, \\ Daniel J. Conley ${ }^{4}$, and Emma S. Kritzberg ${ }^{5}$ \\ ${ }^{1}$ Interdisciplinary Ecology group, Department of Biology, University of the Balearic Islands, 07122, Palma, Spain \\ ${ }^{2}$ National Institute of Aquatic Resources, Section for Oceanography and Marine Ecology, Technical University \\ of Denmark, Charlottenlund, Denmark \\ ${ }^{3}$ Centre for Ecology and Evolution in Microbial model Systems, EEMiS, Linnaeus University, 39182 Kalmar, Sweden \\ ${ }^{4}$ Department of Geology, Lund University, 223 62, Lund, Sweden \\ ${ }^{5}$ Department of Biology, Lund University, 223 62, Lund, Sweden \\ ${ }^{a}$ present address: Department of Oceanography, Center for Microbial Oceanography Research and \\ Education (C-MORE), University of Hawaii at Manoa, 96822, Honolulu, USA
}

Correspondence to: Raquel Vaquer-Sunyer (raquel.vaquer@uib.cat)

Received: 14 April 2016 - Published in Biogeosciences Discuss.: 18 April 2016

Revised: 27 July 2016 - Accepted: 3 August 2016 - Published: 23 August 2016

\begin{abstract}
The Baltic Sea is the world's largest area suffering from eutrophication-driven hypoxia. Low oxygen levels are threatening its biodiversity and ecosystem functioning. The main causes for eutrophication-driven hypoxia are high nutrient loadings and global warming. Wastewater treatment plants (WWTP) contribute to eutrophication as they are important sources of nitrogen to coastal areas. Here, we evaluated the effects of wastewater treatment plant effluent inputs on Baltic Sea planktonic communities in four experiments. We tested for effects of effluent inputs on chlorophyll $a$ content, bacterial community composition, and metabolic rates: gross primary production (GPP), net community production (NCP), community respiration $(\mathrm{CR})$ and bacterial production (BP). Nitrogen-rich dissolved organic matter (DOM) inputs from effluents increased bacterial production and decreased primary production and community respiration. $\mathrm{Nu}$ trient amendments and seasonally variable environmental conditions lead to lower alpha-diversity and shifts in bacterial community composition (e.g. increased abundance of a few cyanobacterial populations in the summer experiment), concomitant with changes in metabolic rates. An increase in BP and decrease in CR could be caused by high lability of the DOM that can support secondary bacterial production,
\end{abstract}

without an increase in respiration. Increases in bacterial production and simultaneous decreases of primary production lead to more carbon being consumed in the microbial loop, and may shift the ecosystem towards heterotrophy.

\section{Introduction}

The Baltic Sea has the largest area affected by eutrophication-driven hypoxia (Conley et al., 2011). Eutrophication is expanding in the Baltic Sea; from 2007 to 2011 the entire open Baltic was found to be eutrophic (Fleming-Lehtinen et al., 2015). A 10-fold increase in the hypoxic area has been recorded for the last 115 years, mostly related to increased nutrient inputs from land (Carstensen et al., 2014). The lack of oxygen in marine waters causes death of marine organisms and catastrophic changes in marine metazoan communities. Thus, hypoxia is emerging as a major threat to marine biodiversity (Vaquer-Sunyer and Duarte, 2008), although prokaryotic diversity can increase in oxygen minimum zones (Wright et al., 2012).

Municipal wastewater treatment plants (WWTPs) contribute to eutrophication because they are a substantial source 
of nitrogen $(\mathrm{N})$ to natural waters worldwide (Seitzinger et al., 2005). To reduce the environmental impact of WWTP effluent discharge, limits on the concentration of nitrogen have been imposed. In the European Union, the "Urban Waste Water Directive" (91/271/EEC) sets the discharge limit of effluents from urban wastewater treatment plants for total nitrogen $(\mathrm{TN})$ between 10 and $15 \mathrm{mg} \mathrm{N} \mathrm{L}^{-1}(714-1071 \mu \mathrm{M})$, depending on the number of population equivalents. In other regions, such as Chesapeake Bay, the largest US estuary that experiences severe hypoxic conditions, discharge limits range from 3 to $8 \mathrm{mg} \mathrm{N} \mathrm{L}^{-1}$ (214-571 $\mu \mathrm{M}$, Chesapeake Bay Program 2006). Both areas, the Baltic Sea and Chesapeake Bay, are enclosed water bodies with excessive anthropogenic nutrient inputs. Wastewater treatment plants contribute 10$20 \%$ of total nutrient loading in the Baltic Sea (Hautakangas et al., 2014). Estimates of total nitrogen loads to the Baltic Sea due to WWTP effluents are about $110000 \mathrm{t}$ of nitrogen per year, and for total phosphorus loads are around $11000 \mathrm{t}$ of phosphorus per year (Hautakangas et al., 2014). Some Baltic countries have implemented nutrient reductions in their WWTP. Denmark and Germany have reduced both nitrogen and phosphorus loadings significantly. Sweden and Finland have reduced phosphorus loads but have failed so far in reducing nitrogen loads down to $70 \%$ as recommended by HELCOM (2009; Hautakangas et al., 2014).

Effluent from WWTPs includes both dissolved inorganic (DIN) and organic N (DON). The conventional biological treatment (secondary treatment) combines coupled nitrification/denitrification and can potentially reduce $\mathrm{TN}$ to around 8-12 $\mathrm{mg} \mathrm{N} \mathrm{L}^{-1}$ (571-857 $\mu \mathrm{M}$; Bronk et al., 2010). Biological treatment can eliminate most of the DIN, leading to a substantial fraction of the residual $\mathrm{N}$ in effluent as DON (Bronk et al., 2010; Grady et al., 2011). Effluents also contribute to increased organic matter (OM) inputs to coastal areas.

DON can play an active role in providing nutrition to both phytoplankton and bacteria (Berman and Bronk, 2003) and affects planktonic metabolism in areas receiving significant amounts of DON. Dissolved organic matter (DOM) inputs to coastal areas can also affect metabolic rates and favour bacterial processes (Berglund et al., 2007). Here, we investigated the effects of wastewater treatment plant (WWTP) effluent inputs on planktonic metabolic rates in the Baltic Sea. We did so on the basis of four experiments where WWTP inputs were added to natural communities. We tested for effects of effluent inputs on metabolic rates: gross primary production (GPP), net community production (NCP), community respiration (CR) and bacterial production (BP); on chlorophyll $a$ content; and on bacterial community composition.

\section{Methods}

\subsection{Sampling}

Natural marine planktonic communities from the Baltic Sea Proper were collected (sampling dates included in Table 1) $10 \mathrm{~km}$ off the east coast of Öland, Sweden, at the Linnaeus Microbial Observatory (LMO; 56 $55.851 \mathrm{~N}, 17^{\circ} 03.640 \mathrm{E}$ ). The water was sampled from $2 \mathrm{~m}$ depth and filtered through a $150 \mu \mathrm{m}$ net to remove large grazers.

Wastewater effluent was collected within 10 days prior to experiment (sampling dates included in Table 2) from the wastewater treatment plant (WWTP) in Kalmar for effluent enrichment. Samples from WWTP were filtered using precombusted $\left(450^{\circ} \mathrm{C}, 4 \mathrm{~h}\right)$ glass-fibre $(\mathrm{GF} / \mathrm{F}$ Whatman) filters and $0.2 \mu \mathrm{m}$ membrane filters and frozen until the start of the experiment. All equipment used for handling the samples was acid-washed.

\subsection{Treatments}

Four experiments were performed to cover all seasons spring, summer, autumn and winter - to be able to measure seasonal variation in both planktonic communities and effluent characteristics under different environmental conditions. Each experiment consisted of five different treatments, three of them with different additions: one with WWTP addition in a proportion of $1: 10 \mathrm{vol}: \mathrm{vol}$ in seawater $(1: 10)$, a second with WWTP addition in a proportion of $1: 5(1: 5)$, and a treatment with addition of inorganic nutrients (nitrate, nitrite and phosphate) equivalent to that contained in the DON $1: 5$ treatment (IN). Those three treatments $(1: 10,1: 5$ and IN) were performed to contain the same portion of community, so the $1: 10$ and the IN treatments were diluted with autoclaved Milli-Q and salt solution to obtain the same community portion than the $1: 5$ treatment. There was a control (C) treatment with only seawater and a diluted control (CD) consisting of seawater diluted with autoclaved Milli-Q water to have the same portion of community that the $1: 10,1: 5$ and IN treatments. To keep salinity constant in all treatments, a salt solution (Søndergaard et al., 2003) was added with the amendments/dilutions.

\subsection{Metabolic rates}

Changes in dissolved oxygen (DO) in closed bottles were assumed to result from biological metabolic processes and to represent net community production $(\mathrm{NCP}=\mathrm{GPP}-\mathrm{CR})$. Water from the respective treatments was siphoned carefully to avoid bubble formation into four $2.3 \mathrm{~L}$ glass bottles per treatment sealed with gas-tight stoppers. Bottles were incubated at the in situ temperature (Tables 1 and S1 in the Supplement) in a temperature-controlled chamber during 1 week. Oxygen was measured every minute in two of the four replicate bottles using optical oxygen sensors (optodes) and a 10channel fibre optic oxygen transmitter (oxy-10, PreSens ${ }^{\circledR}$ ). 
Table 1. Physicochemical parameters in coastal seawater for the different sampled seasons. Standard errors (SE) are derived from duplicate sample analysis. $\mathrm{C}: \mathrm{N}$ ratio is calculated as the ratio DOC : DON (moles).

\begin{tabular}{lllll}
\hline & Winter & Spring & Summer & Autumn \\
\hline Date & $23 / 01 / 2013$ & $03 / 04 / 2013$ & $18 / 07 / 2013$ & $04 / 11 / 2013$ \\
$\mathrm{TDN}( \pm \mathrm{SE})(\mu \mathrm{M})$ & $17.01( \pm 0.87)$ & $16.40( \pm 0.63)$ & $16.51( \pm 0.08)$ & $20.99( \pm 0.34)$ \\
$\mathrm{NO}_{2}^{-}( \pm \mathrm{SE})(\mu \mathrm{M})$ & $0.35( \pm 0.02)$ & $0.14( \pm 0.00)$ & $0.09( \pm 0.01)$ & $0.31( \pm 0.21)$ \\
$\mathrm{NO}_{3}^{-}( \pm \mathrm{SE})(\mu \mathrm{M})$ & $4.93( \pm 0.39)$ & $3.69( \pm 0.14)$ & $0.50( \pm 0.09)$ & $2.64( \pm 0.32)$ \\
$\mathrm{NH}_{4}^{+}( \pm \mathrm{SE})(\mu \mathrm{M})$ & $0.35( \pm 0.01)$ & $0.01( \pm 0.01)$ & $0.24( \pm 0.00)$ & $0.23( \pm 0.03)$ \\
$\mathrm{PO}_{4}^{3-}( \pm \mathrm{SE})(\mu \mathrm{M})$ & $0.55( \pm 0.03)$ & $0.63( \pm 0.03)$ & $0.03( \pm 0.01)$ & $0.39( \pm 0.02)$ \\
$\mathrm{DON}( \pm \mathrm{SE})(\mu \mathrm{M})$ & $11.44( \pm 0.95)$ & $12.56( \pm 0.64)$ & $15.76( \pm 0.12)$ & $17.91( \pm 0.47)$ \\
$\mathrm{DPA}( \pm \mathrm{SE})(\mu \mathrm{M})$ & $0.09( \pm 0.01)$ & $0.31( \pm 0.01)$ & $0.17( \pm 0.01)$ & $0.24( \pm 0.03)$ \\
$\mathrm{DOC}( \pm \mathrm{SE})(\mu \mathrm{M})$ & $483.11( \pm 68.40)$ & $297.36( \pm 3.08)$ & 474.56 & $318.44( \pm 9.42)$ \\
$\mathrm{DON} \%$ of TDN & 67.03 & 76.58 & 95.48 & 85.33 \\
Temperature $\left({ }^{\circ} \mathrm{C}\right)$ & 3 & 4 & 18 & 7 \\
Salinity & 6.30 & 6.10 & 6.3 & 7.3 \\
Chlorophyll $\left.a(\mu \mathrm{g} \mathrm{L})^{-1}\right)$ & $0.30( \pm 0.00)$ & $2.34( \pm 0.27)$ & $6.49( \pm 0.01)$ & $1.76( \pm 0.04)$ \\
$\mathrm{C} / \mathrm{N}$ ratio & 42.23 & 23.68 & 30.11 & 17.78 \\
\hline
\end{tabular}

Table 2. Wastewater effluent nutrient content for the different seasons sampled. C: $\mathrm{N}$ ratio is calculated as the ratio DOC : DON (moles).

\begin{tabular}{lllll}
\hline & Winter & Spring & Summer & Autumn \\
\hline Date & $23 / 01 / 2013$ & $03 / 04 / 2013$ & $16 / 07 / 2013$ & $25 / 10 / 2013$ \\
$\mathrm{TDN}( \pm \mathrm{SE})(\mu \mathrm{M})$ & $600.12( \pm 6.56)$ & $576.20( \pm 3.20)$ & $518.39( \pm 2.39)$ & $498.20( \pm 9.77)$ \\
$\mathrm{NO}_{2}^{-}( \pm \mathrm{SE})(\mu \mathrm{M})$ & 8.00 & 32.74 & $29.44( \pm 0.04)$ & 29.29 \\
$\mathrm{NO}_{3}^{-}( \pm \mathrm{SE})(\mu \mathrm{M})$ & 81.00 & $113.64( \pm 2.17)$ & $192.00( \pm 6.38)$ & 228.57 \\
$\mathrm{NH}_{4}^{+}( \pm \mathrm{SE})(\mu \mathrm{M})$ & 7.76 & & $117.93( \pm 1.20)$ & $165.15( \pm 1.21)$ \\
$\mathrm{PO}_{4}^{3-}( \pm \mathrm{SE})(\mu \mathrm{M})$ & 0.02 & & & 0.19 \\
$\mathrm{DON}( \pm \mathrm{SE})(\mu \mathrm{M})$ & $503.35( \pm 2.93)$ & $429.83^{*}$ & $179.02( \pm 7.95)$ & $75.20( \pm 4.39)$ \\
$\mathrm{DPA}( \pm \mathrm{SE})(\mu \mathrm{M})$ & & $18.71(2.64)$ & $2.64( \pm 0.17)$ & \\
$\mathrm{DOC}( \pm \mathrm{SE})(\mu \mathrm{M})$ & $1347.96( \pm 205.65)$ & $924.18(6.66)$ & $1082.37( \pm 2.50)$ & $706.87( \pm 9.99)$ \\
$\mathrm{DON} \%$ of TDN & 83.88 & $74.60^{*}$ & 34.53 & 15.09 \\
$\mathrm{C} / \mathrm{N}$ ratio & 2.68 & 2.15 & 6.05 & 9.40 \\
\hline
\end{tabular}

* Calculated without $\mathrm{NH}_{4}^{+}$concentration (overestimation).

The remaining two bottles per treatment were used to sample for nutrient and chlorophyll $a$ concentrations.

Incubations were illuminated by artificial light (OSRAM L36W/865 Lumilux Daylight), with a photosynthetically active radiation intensity of $1373.2 \mu \mathrm{W} \mathrm{cm} \mathrm{cm}^{-2}$. Light hours ranged from $8 \mathrm{~h} 30 \mathrm{~m}$ for the winter experiment performed on January 2013 to $16 \mathrm{~h} 30 \mathrm{~m}$ for the summer experiment on July 2013. This irradiation dose corresponds approximately to the irradiation received at a depth of $2.5 \mathrm{~m}$ in the winter and $7 \mathrm{~m}$ in the summer, at Kalmar, Sweden (Strång Model, SMHI, 2016).

NCP was estimated as the changes in DO content during $24 \mathrm{~h}$ intervals $(\mathrm{dDO} / \mathrm{d} t)$. CR was calculated from the rate of change in DO during the night from half an hour after lights went of to half an hour before light went on. CR was assumed to be the same during light and dark. NCP in darkness equals CR during night. GPP was estimated as the sum of NCP and CR $(\mathrm{GPP}=\mathrm{NCP}+\mathrm{CR})$. Individual estimates of
GPP, NCP and CR resolved at 1 min intervals were accumulated over each $24 \mathrm{~h}$ period during experiments and reported in $\mathrm{mmol} \mathrm{O}_{2} \mathrm{~m}^{-3} \mathrm{day}^{-1}$; a detailed description of calculation of metabolic rates can be found at Vaquer-Sunyer et al. (2015).

As incubations were performed following a natural light regime to mimic natural conditions, results may differ from incubations performed at light and dark conditions in parallel. Both approaches assume equal respiration rates under light and dark conditions. This assumption may lead to underestimation of CR and GPP, as respiration rates are probably higher during daylight than at night (Grande et al., 1989; Pace and Prairie, 2005; Pringault et al., 2007), but it does not affect NCP estimates (Cole et al., 2000). In incubations performed under dark conditions, phytoplankton growth is suppressed, decreasing phytoplankton respiration contribution to community respiration. 


\section{Bacterial production}

BP was estimated by measuring incorporation of ${ }^{3} \mathrm{H}$-leucine following the method established by Smith and Azam (1992) on days $0,1,3,5$ and 7 . Water samples $(1.5 \mathrm{~mL}$, three replicates and one killed control with $5 \%$ trichloroacetic acid, TCA) were incubated $60 \mathrm{~min}$ with $98.8 \mathrm{nM}$ of ${ }^{3} \mathrm{H}$-leucine (13.4 $\left.\mathrm{Ci} \mathrm{mmol}^{-1}\right)$ in the temperature-controlled room, at the same incubation temperature and light irradiance as the rest of the samples. The incubation was terminated by adding TCA $5 \%$ final concentration. The samples were then centrifuged at $16000 \mathrm{~g}$ for $10 \mathrm{~min}$ and the bacterial pellet was washed once with 5\% TCA and once with $80 \%$ ethanol. After the supernatant was discarded, $0.5 \mathrm{~mL}$ of scintillation cocktail (Ecoscint A, Kimberly Research) was added and ${ }^{3} \mathrm{H}$ activity measured on a Beckman LS 6500 scintillation counter. BP was calculated according to Smith and Azam (1992) assuming a leucine to carbon conversion factor of $1.5 \mathrm{~kg} \mathrm{C} \mathrm{mol}^{-1}$ leucine (Kirchman, 2001).

\subsection{Chlorophyll $a$, dissolved organic carbon and nutrient measurements}

Samples for chlorophyll $a$ (Chl $a$ ), dissolved organic carbon (DOC) and nutrients were taken on days $0,1,3,5$ and 7 from the two $2.3 \mathrm{~L}$ bottles for each treatment incubated in parallel with the bottles used to monitor oxygen changes. Samples were taken in duplicate. For the last day of the experiment (day 7), the two bottles used to monitor oxygen content were used to sample Chl $a$, DOC and nutrient content. Samples for nutrient determination were filtered using pre-combusted $\left(450^{\circ} \mathrm{C}, 4 \mathrm{~h}\right)$ glass-fibre (GF/F Whatman) filters and $0.2 \mu \mathrm{m}$ membrane filters and frozen until analysis. All equipment used for handling the samples was acid-washed.

Chlorophyll $a$ was measured in duplicate following Jespersen and Christoffersen (1987) on a Turner TD-700 fluorometer.

DOC was measured on a Shimadzu TOC V-CPN in nonpurgeable organic carbon (NPOC) mode on acidified samples ( $\mathrm{HCl}$ to $\mathrm{pH}<2)$. The instrument was calibrated daily with potassium hydrogen phthalate. DOC concentrations were calculated from the average area of three injections, with an area covariance of less than $2 \%$.

Total dissolved nitrogen (TDN) was measured in duplicate after persulfate oxidation. The method of persulfate oxidation was chosen instead of high-temperature combustion (HTC), as it has been demonstrated to be more appropriate for eutrophic waters, such as the Baltic Sea, as well as coastal areas (Bronk et al., 2000). Inorganic nutrient analyses (nitrate $\left(\mathrm{NO}_{3}^{-}\right)$, nitrite $\left(\mathrm{NO}_{2}^{-}\right)$and phosphate; $\left.\mathrm{PO}_{4}^{3-}\right)$ were analysed in duplicate on an automated nutrient analyser $\left(\mathrm{SmartChem}^{\circledR}\right.$ 200). Concentration of ammonium $\left(\mathrm{NH}_{4}^{+}\right)$was measured in duplicate on a spectrophotometer following the manual phenol hypochlorite method by (Koroleff, 1983). The concentration of DON was calculated by difference after subtracting the concentration of $\mathrm{NH}_{4}^{+}, \mathrm{NO}_{3}^{-}$, and $\mathrm{NO}_{2}^{-}$from the TDN concentration. Dissolved primary amine (DPA) concentrations were measured in triplicate on a spectrofluorometer following the OPA ( $o$-phthaldialdehyde) method (Parsons et al., 1984).

\subsection{Bacterial diversity}

Bacterial 16S rRNA gene fragments were amplified with bacterial primers 341F and 805R (Herlemann et al., 2011) following the PCR protocol of Hugerth et al. (2014) with some modifications. We thus performed a two-step PCR: (i) amplification with the main forward and reverse primers 341F-805R to amplify the correct fragment within the V3V4 hypervariable region of the $16 \mathrm{~S}$ rRNA gene and (ii) amplification using template from the first PCR to attach the handles and indexes needed to run the Illumina Miseq run and for barcoding individual samples. Amplification was carried out in duplicates for each biological replicate using an annealing temperature of $58^{\circ} \mathrm{C}$ in the first PCR and $12 \mathrm{cy}-$ cles in the second PCR. The resulting purified amplicons were sequenced on the Illumina Miseq (Illumina, USA) platform using the $300 \mathrm{bp}$ paired-end setting at the Science for Life Laboratory, Sweden (www.scilifelab.se). Raw sequence data generated from Illumina Miseq were processed using the UPARSE pipeline (Edgar, 2013). Taxonomy was determined against the SINA/SILVA database (SILVA 115; Quast et al., 2013). After quality control, our data consisted of a total of 3.8 million reads, with an average of $68218.61 \pm 33048.86$ reads per sample. These sequences resulted in a final operational taxonomic unit (OTU) table consisting of 3420 OTUs (excluding singletons) delineated at $97 \%$ 16S rRNA gene identity. DNA sequences have been deposited in the National Center for Biotechnology Information (NCBI) Sequence Read Archive under accession number SRP059501.

\subsection{Statistics}

Relationships between chlorophyll a concentration and physicochemical parameters (nitrate concentration, light hours and temperature) were tested by fitting ordinary leastsquares regression.

Metabolic rates data from the four experiments were combined to test the relationship between the given metabolic rates and physicochemical parameters (Table 1) by mixedeffects models. Physicochemical parameters were chosen avoiding collinearity. Selected variables were DOC, DON, nitrate and phosphate concentration. We used DOC as a proxy for dissolved organic matter (DOM). Variables were selected according to its significance. Variables were removed from the model following its $p$ value (i.e. variables with higher $p$ value were removed first) until all variables were significant. To account for pseudo-replication we used incubation day nested to season (i.e. experiment) as a random 
factor. The pseudo- $R^{2}$ of the models was calculated following Xu (2003).

Differences in community composition between treatments were tested using permutational analysis of variance (PERMANOVA) on Bray-Curtis distances. To test the correlation between absolute changes in environmental conditions, metabolic rates and absolute shifts in bacterioplankton community composition, we performed MANTEL tests. For alpha-diversity measures we subsampled each sample to 10000 sequences. Analyses performed at the OTU level were based on selecting the top 200 most abundant OTUs. For OTU level analyses on Cyanobacteria we selected OTUs affiliated with Cyanobacteria among the top 200 most abundant OTUs. Taxonomic annotation from SINA/SILVA database was limited for cyanobacterial OTUs and we therefore extended the annotation by using BLASTn (NCBI). For all analyses on community composition we examined the following eight major phyla/classes: Actinobacteria, Bacteroidetes, Alphaproteobacteria, Betaproteobacteria, Gammaproteobacteria, Cyanobacteria, Planctomycetes, and Verrucomicrobia. All other phyla/classes were grouped together and defined as "Others". All statistical tests were performed in R 3.0.2 ( $\mathrm{R}$ Core Team, 2014) and using the package "vegan" (Oksanen et al., 2007). Graphical outputs were made using the package "ggplot2" (Wickham, 2009). Phylogenetic analyses using maximum likelihood trees were performed with MEGA 6.0.6 and the Tamura-Nei model (Tamura et al., 2011).

\section{Results}

Treated wastewater nutrient content differed between seasons (Table 2). The highest TDN values were measured in winter $(600.1 \pm 6.6 \mu \mathrm{M})$, whereas the lowest values were measured in summer $(518.4 \pm 2.4 \mu \mathrm{M})$. DON content in wastewater effluent varied between $75.2 \pm 4.4 \mu \mathrm{M}$ in autumn and $503.3 \pm 2.9 \mu \mathrm{M}$ during winter. The DOC:DON ratio was low (2.1-9.4), indicating nitrogen-rich dissolved organic matter (DOM). In summer and spring, phosphate content in the effluent was below detection limit $\left(30 \mu \mathrm{g} \mathrm{L}^{-1}\right.$, Table 2$)$.

Nutrient content in the seawater also differed between seasons (Table 1), with the highest TDN value in autumn $(21.0 \pm 0.30 \mu \mathrm{M})$, and the lowest values were measured in spring $(16.4 \pm 0.6 \mu \mathrm{M})$. DON content in coastal water ranged between $11.4 \pm 0.9$ and $17.9 \pm 0.5 \mu \mathrm{M}$, measured in winter and autumn, respectively.

\subsection{Chlorophyll $a$}

Coastal waters showed a typical seasonal pattern (Vahtera et al., 2007), with low chlorophyll $a(\mathrm{Chl} a)$, and high nutrient content in winter; in spring, with the increase in solar radiation, Chl $a$ increased, and inorganic nutrients started to decrease. In summer, with high temperature and high sunlight
Table 3. Statistics for the fitted models for the different metabolic rates and the variables that explain its variability; to account for pseudo-replication, incubation day nested to season (i.e. experiment) was included as random factor. $p$ was calculated comparing nested models. SE: standard error; $N$ : number of observations.

\begin{tabular}{lrrrrrr}
\hline & Estimate & SE & $t$ Ratio & $p$ & $R^{2}$ & $N$ \\
\hline GPP & & & & & 0.84 & 73 \\
Intercept & 27.71 & 5.45 & 5.09 & & & \\
DOC $(\mu \mathrm{M})$ & -0.007 & 0.007 & -0.97 & $<0.0001$ & & \\
CR & & & & & 0.84 & 73 \\
Intercept & 23.02 & 3.37 & 6.83 & & & \\
DOC $(\mu \mathrm{M})$ & -0.006 & 0.005 & -1.38 & $<0.0001$ & & \\
NCP & & & & & 0.79 & 77 \\
Intercept & 4.85 & 2.68 & 1.81 & & & \\
DOC $(\mu \mathrm{M})$ & -0.002 & 0.004 & -0.41 & $<0.0001$ & & \\
BP & & & & & 0.91 & 92 \\
Intercept & 1.11 & 0.45 & 2.47 & & & \\
DOC $(\mu \mathrm{M})$ & 0.001 & 0.001 & 1.30 & $<0.0001$ & & \\
Nitrate $(\mu \mathrm{M})$ & 0.02 & 0.004 & 5.17 & $<0.0001$ & & \\
Phosphate $(\mu \mathrm{M})$ & -1.00 & 0.32 & -3.12 & $<0.003$ & & \\
DON $(\mu \mathrm{M})$ & 0.02 & 0.01 & 2.19 & $<0.03$ & & \\
\hline
\end{tabular}

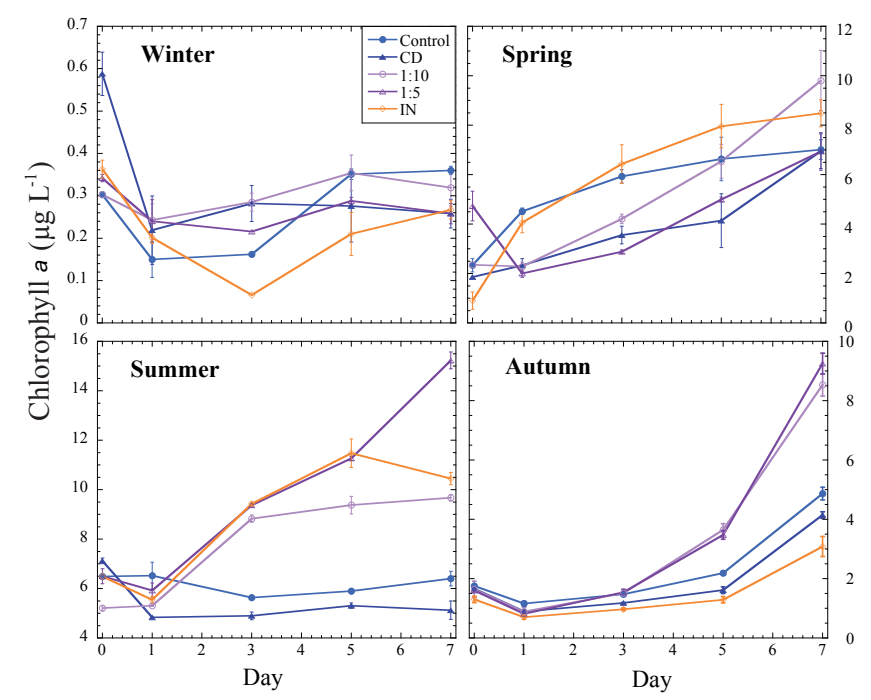

Figure 1. Chlorophyll $a$ content for the different incubation days and different treatments for the four experiments.

radiation, $\mathrm{Chl} a$ values increased to the maximum measured, and inorganic nutrients were depleted (Table 1). During autumn, Chl $a$ content decreased to the second lowest values and nutrient concentration started to replenish (Table 1).

Chlorophyll $a$ content strongly depended on light availability $\left(p<0.0001, R^{2}=0.60\right)$ and on temperature $\left(p<0.0001, R^{2}=0.41\right)$, with the summer experiment having the highest values (mean $\pm \mathrm{SE}=7.59 \pm 0.41 \mu \mathrm{g} \mathrm{L}{ }^{-1}$ ), with 16.5 light hours and a mean temperature of $18.4^{\circ} \mathrm{C}$ (Fig. 1, Supplement Table S1). In total, $66 \%$ of $\mathrm{Chl} a$ variation could be explained by changes in light exposure time and $\mathrm{NO}_{3}^{-}$ concentration $(p<0.0001)$. 


\subsection{Metabolic rates}

\subsubsection{Gross primary production}

Gross primary production (GPP) for natural communities in the experiments varied from $2.03 \pm 2.00$ to $54.16 \pm 5.31 \mathrm{mmol} \mathrm{O}_{2} \mathrm{~m}^{-3} \mathrm{~d}^{-1}$, both extremes measured on the fifth day of the experiment, for experiments conducted in winter and summer, respectively. In the amended treatments, GPP also varied greatly between days of experiment and seasons, with the lowest measured GPP being $0.14 \pm 1.91 \mathrm{mmol} \mathrm{O}_{2} \mathrm{~m}^{-3} \mathrm{~d}^{-1}$ for the 5 th day of the $1: 10$ treatment in the experiment conducted in winter; and the highest measured GPP was $85.67 \pm 7.13 \mathrm{mmol} \mathrm{O}_{2} \mathrm{~m}^{-3} \mathrm{~d}^{-1}$ on the final day (day 7) of the inorganic nutrient addition treatment in summer (Fig. 2).

GPP variability was explained by differences in DOC concentration (Table 3), with this variable explaining $84 \%$ of its variability (Fig. 3a). GPP decreased with DOC concentration (Table 3).

\subsubsection{Community respiration}

Community respiration (CR) for natural waters in the experiments varied between $5.30 \pm 0.99$ and $34.89 \pm 1.35 \mathrm{mmol} \mathrm{O}_{2} \mathrm{~m}^{-3} \mathrm{~d}^{-1} \quad$ (Table $\mathrm{S} 1$ ). CR varied greatly between treatments, days of experiment and seasons. $\mathrm{CR}$ varied from $0.95 \pm 1.32 \mathrm{mmol} \mathrm{O}_{2} \mathrm{~m}^{-3} \mathrm{~d}^{-1}$ for the day 1 on the IN treatment from the winter experiment to $54.16 \pm 55.59 \mathrm{mmol} \mathrm{O}_{2} \mathrm{~m}^{-3} \mathrm{~d}^{-1}$ for the final day on the $1: 5$ treatment during the autumn experiment (Fig. 4). The high SD associated to these measures is due to differences between incubation bottles.

CR was inversely correlated with DOC concentration, with this variable explaining the $84 \%$ of CR variability (Table 3, Fig. 3b).

\subsubsection{Net community production}

Net community production (NCP) for natural communities in the experiments varied between -8.83 and $20.17 \pm 5.78 \mathrm{mmol} \mathrm{O}_{2} \mathrm{~m}^{-3} \mathrm{~d}^{-1}$ measured in autumn and in summer, respectively. The range of variability in the treatments with nutrient additions was wider, ranging from $-16.64 \pm 17.69$ to $36.69 \pm 1.49 \mathrm{mmol} \mathrm{O}_{2} \mathrm{~m}^{-3} \mathrm{~d}^{-1}$ measured on day 1 of the $1: 10$ treatment in the winter experiment and on day 7 of the IN treatment during the summer experiment, respectively (Fig. 5). NCP varied greatly between day of experiment, season and treatment.

NCP was dependent on DOC concentration, with this variable explaining the $79 \%$ of its variability (Table 3, Fig. 3c). NCP significantly decreased with DOC content $(p<0.0001$, Table 3).

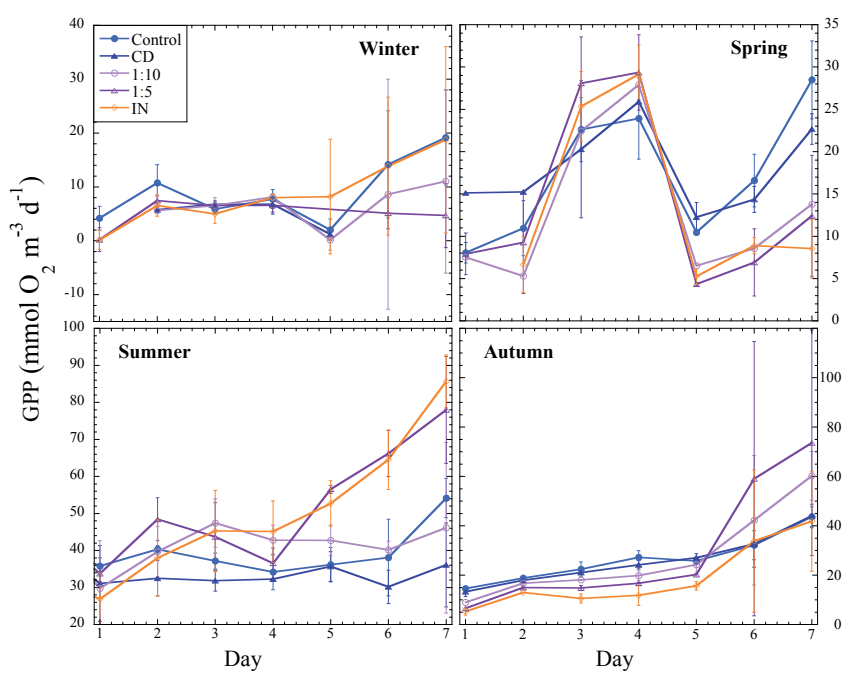

Figure 2. Gross primary production (GPP) in $\mathrm{mmol} \mathrm{O}_{2} \mathrm{~m}^{-3} \mathrm{~d}^{-1}$ measured the seven incubation days for the different treatments and experiments.
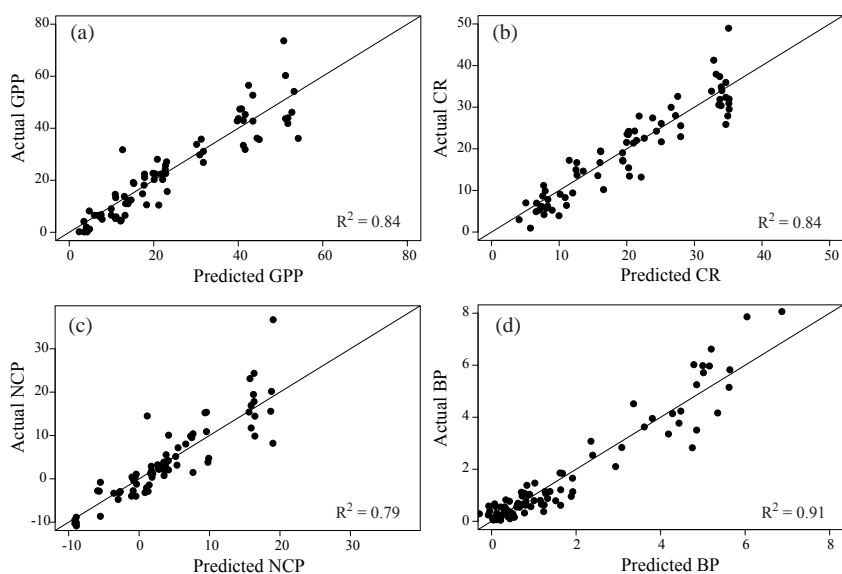

Figure 3. Comparison of actual values and values predicted by the mixed-effects model for (a) gross primary production (GPP), (b) community respiration (CR), (c) net community production (NCP) and (d) bacterial diversity. Black solid line represents the $1: 1$ line.

\subsubsection{Bacterial production}

Bacterial production (BP) tended to increase in the treatment with the higher addition of effluent (Fig. 6). Repeated measures MANOVA showed significant differences in BP for different sampling days, for treatments and for the interaction between sampling day and treatment for experiments conducted in summer and autumn ( $p<0.0001$ for both cases). Conversely, BP was not significantly different between treatments for experiments conducted in spring and winter. For those experiments there were significant differences in BP between sampling days and in the interaction between treatment and sampling day. 
Table 4. Results of MANTEL tests (Pearson's $r$ ) to examine whether absolute shifts in bacterioplankton community composition were correlated with absolute changes specific environmental variables and metabolic rates measured in the incubations during the experiments. Significance is indicated in parentheses.

\begin{tabular}{|c|c|c|c|c|c|}
\hline & All & Winter & Spring & Summer & Autumn \\
\hline Date & - & $23 / 01 / 2013$ & $03 / 04 / 2013$ & $18 / 07 / 2013$ & $04 / 11 / 2013$ \\
\hline Temperature & $0.5118\left(0.001^{*}\right)$ & $0.1481(0.299)$ & $0.208(0.123)$ & $0.1582(0.558)$ & $-0.01759(0.489)$ \\
\hline $\mathrm{NCP}$ & $0.05345(0.149)$ & $-0.2466(0.689)$ & $0.2233(0.089)$ & $0.05968(0.242)$ & $-0.06(0.573)$ \\
\hline GPP & $0.2095\left(0.004^{*}\right)$ & $-0.2182(0.591)$ & $-0.1855(0.795)$ & $0.1588(0.09)$ & $0.08498(0.277)$ \\
\hline $\mathrm{CR}$ & $0.2651\left(0.001^{*}\right)$ & $-0.4532(0.862)$ & $-0.211(0.874)$ & $0.2085\left(0.044^{*}\right)$ & $0.385\left(0.014^{*}\right)$ \\
\hline $\mathrm{BP}$ & $0.3208\left(0.001^{*}\right)$ & $-0.1194(0.627)$ & $0.3048\left(0.047^{*}\right)$ & $-0.04983(0.658)$ & $0.1228(0.218)$ \\
\hline Chl $a$ & $0.2147\left(0.001^{*}\right)$ & $0.1021(0.396)$ & $0.1326(0.178)$ & $0.3575\left(0.005^{*}\right)$ & $0.02732(0.398)$ \\
\hline DOC & $0.03036(0.272)$ & $-0.1072(0.600)$ & $0.1926(0.134)$ & $0.269\left(0.035^{*}\right)$ & $0.04995(0.357)$ \\
\hline TDN & $0.1558\left(0.003^{*}\right)$ & $-0.03911(0.513)$ & $-0.04881(0.497)$ & $0.247\left(0.027^{*}\right)$ & $0.04071(0.321)$ \\
\hline $\mathrm{NO}_{2}^{-}$ & $0.1558\left(0.003^{*}\right)$ & $-0.03979(0.531)$ & $-0.04449(0.683)$ & $0.01229(0.376)$ & $0.1027(0.181)$ \\
\hline $\mathrm{NO}_{3}^{-}$ & $0.05622(0.111)$ & $-0.01186(0.457)$ & $-0.06687(0.65)$ & $0.03073(0.328)$ & $0.1416(0.161)$ \\
\hline $\mathrm{NH}_{4}$ & $0.02908(0.311)$ & $0.00467(0.361)$ & $-0.08367(0.611)$ & $-0.00490(0.433)$ & $0.1069(0.195)$ \\
\hline DON & $0.00043(0.391)$ & $-0.09584(0.667)$ & $-0.04767(0.452)$ & $0.136(0.163)$ & $0.03776(0.356)$ \\
\hline DPA & $-0.01335(0.529)$ & $-0.03385(0.49)$ & $-0.1055(0.612)$ & $-0.00163(0.407)$ & $-0.03274(0.532)$ \\
\hline $\mathrm{PO}_{4}^{3-}$ & $0.2982\left(0.001^{*}\right)$ & $0.1492(0.207)$ & ND & $0.2853\left(0.007^{*}\right)$ & $-0.1585(0.819)$ \\
\hline
\end{tabular}

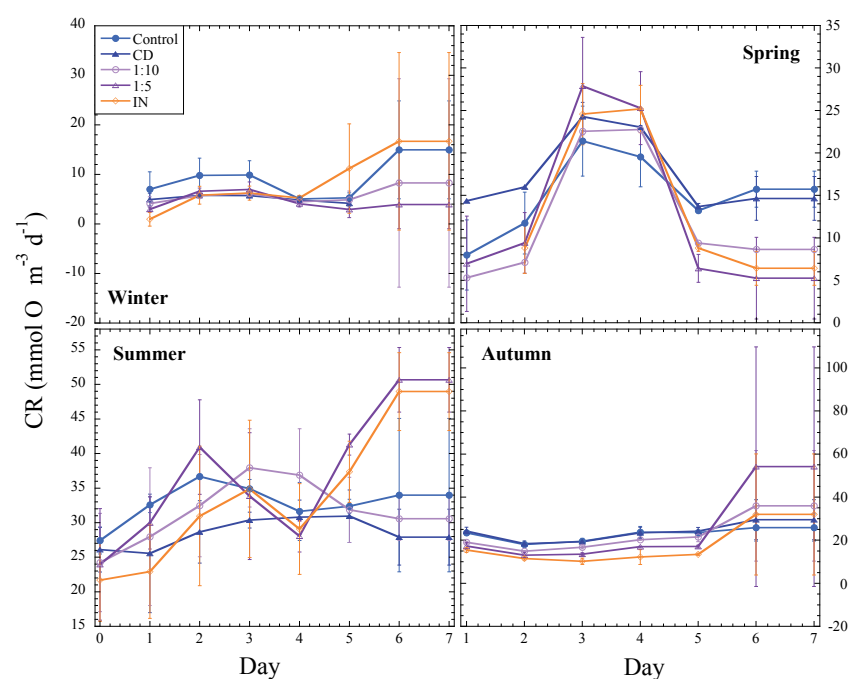

Figure 4. Community respiration (CR) in $\mathrm{mmol} \mathrm{O}_{2} \mathrm{~m}^{-3} \mathrm{~d}^{-1}$ measured the seven incubation days for the different treatments and experiments.

BP was positively correlated with DOC content in spring, summer and winter $(p<0.003, p<0.005$ and $p<0.05$, respectively), but it was independent of DOC concentration in autumn $(p>0.05)$.

The variables that best explained $\mathrm{BP}$ variability were phosphate, DOC, DON and $\mathrm{NO}_{3}^{-}$concentration $\left(R^{2}=0.91\right.$, Table 3, Fig. 3d). BP increased with DOC, DON and nitrate concentration and decreased with phosphate concentration.

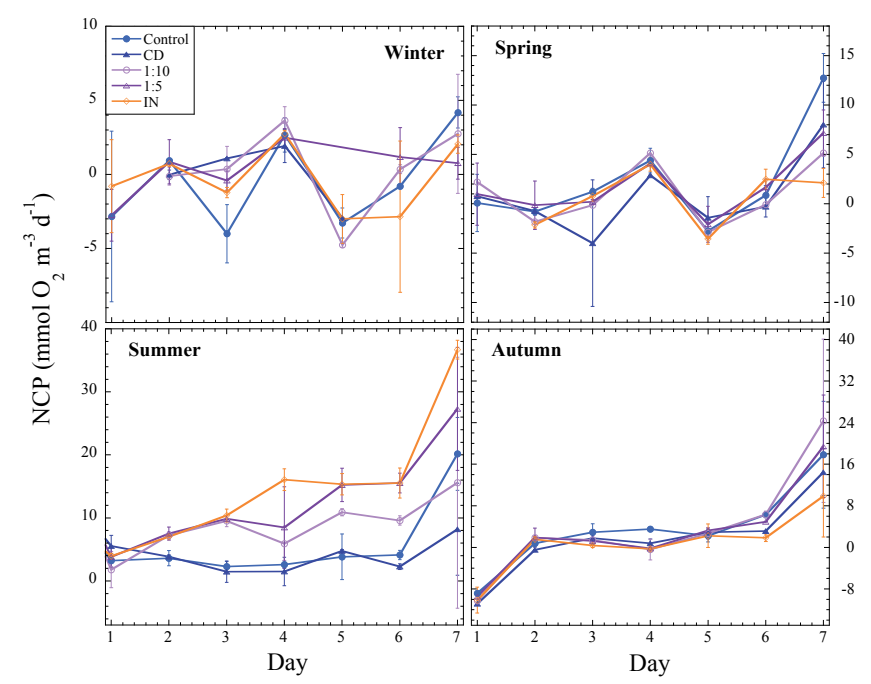

Figure 5. Net community production (NCP) in $\mathrm{mmol} \mathrm{O}_{2} \mathrm{~m}^{-3} \mathrm{~d}^{-1}$ measured the seven incubation days for the different treatments and experiments.

\subsection{Bacterial diversity and community composition}

Bacterial community structure showed two distinct clusters with summer communities separated from spring and winter across all experiments (Fig. S1, Supplement). Community composition in each experiment exhibited, in general, a temporal succession and an additional response to different treatments. We carried out MANTEL tests to elucidate the influence of environmental factors on community composition and metabolic rates. Changes in temperature significantly explained absolute shifts in bacterioplankton commu- 


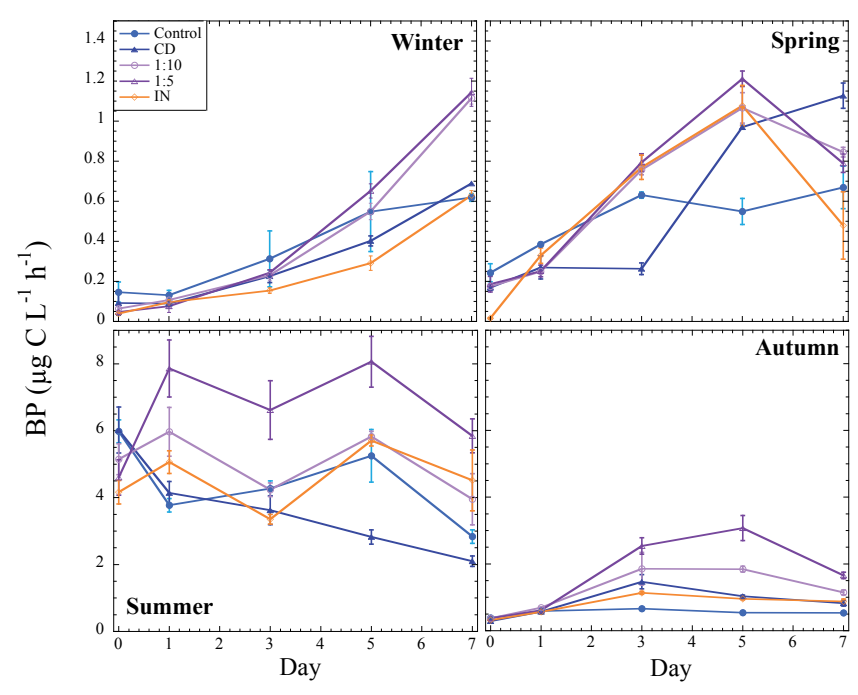

Figure 6. Bacterial production in $\mu \mathrm{gCL}^{-1} \mathrm{~h}^{-1}$ for the different measured days for the different treatments and experiments.

nity composition across all experiments (Pearson $r>0.5$; Table 4). Changes in GPP, $\mathrm{CR}, \mathrm{BP}, \mathrm{Chl} a, \mathrm{NO}_{2}^{-}$and $\mathrm{PO}_{4}^{3-}$ were significantly correlated with absolute shifts in bacterioplankton community composition, with the highest correlation observed for $\mathrm{PO}_{4}^{3-}$ (Pearson $r=0.30$; Table 4).

Alpha-diversity estimated from the Shannon index was relatively similar between treatments in each experiment and ranged from 3.34 to $5.82 \pm 0.51$ (Fig. 7). Nevertheless, a lower Shannon index was observed for all amended treatments compared to the controls in all experiments except April (Fig. 7). Moreover, we analysed the richness and found that the observed number of OTUs ranged between 206 and $946 \pm 171$ and Chao. 1 index values ranged between 306 and $1273 \pm 220$ (Fig. S2). Richness was generally lower in effluent-amended treatments compared to controls, except for in the April experiment.

Betaproteobacteria, Bacteroidetes and Alphaproteobacteria dominated the April experiment, where Betaproteobacteria displayed a marked increase in relative abundance from T0 to T7 (Fig. 8). In general, few differences in community composition between treatments were observed. Nevertheless, Betaproteobacteria decreased in relative abundance by more than half in controls until T7, while they maintained their abundance in the other treatments. For the January experiment, differences between treatments were more pronounced (Fig. 8). Bacterial groups other than the eight major phyla/class ("Others") had nearly 4 -fold higher relative abundance in the $1: 5$ treatment compared to the other treatments and the controls. At T3 Cyanobacteria had considerably higher relative abundance in the $1: 10$ and IN treatments compared to the controls and 1:5 treatment. The July experiment showed a higher relative abundance of Cyanobacteria and Verrucomicrobia, with the relative abundance of Cyanobacteria increasing over time in the amended treat- ments. In contrast, the relative abundance of Verrucomicrobia increased in the control treatments and was highest in the diluted control (CD; Fig. 8). Hence, Cyanobacteria had higher relative abundance in treatments with additions of nutrients (both DON and IN; Fig. 8). For the November experiment there was an overall greater variation in community composition. Still, relative abundances of Gammaproteobacteria increased in the IN treatments at T3 and T7 compared to the other treatments and control.

\subsection{Population dynamics}

Patterns in community composition indicated that effluent amendments had an effect on bacterial population dynamics in our experiments coupled with the concomitant changes in metabolic rates. Hence, we performed Pearson correlation tests to determine links between environmental factors, metabolic rates and shifts in relative abundances at phyla/class level. Shifts in relative abundances of Cyanobacteria, Planctomycetes and Verrucomicrobia were positively correlated with temperature (Fig. 9). In contrast, Alphaproteobacteria, Bacteroidetes and Betaproteobacteria were negatively correlated with temperature. Cyanobacteria, Planctomycetes and Verrucomicrobia displayed a strong negative correlation with community respiration but a positive correlation with bacterial production. These three groups of bacteria were also negatively correlated with $\mathrm{PO}_{4}^{3-}$, while Alphaproteobacteria, Bacteroidetes and Betaproteobacteria were positively correlated with $\mathrm{PO}_{4}^{3-}$. In particular, changes in $\mathrm{PO}_{4}^{3-}$ concentrations explained $>50 \%$ of the variance for Bacteroidetes (Fig. 9). In addition, Verrucomicrobia had a strong correlation with $\mathrm{NO}_{2}^{-}$. Actinobacteria, Gammaproteobacteria and bacterial groups other than the eight major phyla/class ("Others") showed only weak correlations with environmental parameters and metabolic rates.

Changes in relative abundance of particular bacterial populations typically followed the overall pattern within each major phyla/class. For example, Chtoniobacterales OTUs within Verrucomicrobia exhibited positive correlations with temperature and bacterial production but negative correlations with $\mathrm{PO}_{4}^{3-}$ (Fig. S3). Although relative abundances of Gammaproteobacteria showed overall weak correlations with metabolic rates and environmental factors, the relative abundance of specific OTUs in this taxon, such as OTU 001410 and two Halioglobus OTUs (OTU 001149 and OTU 000045), displayed strong correlations (Pearson's $r>0.5$ ) with temperature, bacterial production and community respiration. Betaproteobacteria OTUs showed overall weak correlations with metabolic rates and environmental factors except for two MWH-UniP1-related OTUs (OTU 002372 and OTU 000041). Betaproteobacteria affiliated with BAL58 showed in some cases a substantial correlation (Pearson's $r>0.5$ ) with DOC (OTU 001633, OTU 001481, OTU 000008 and OTU 001907; Fig. S3). Within Alphaproteobacteria most OTUs had weak correlations. However, one particular alpha- 

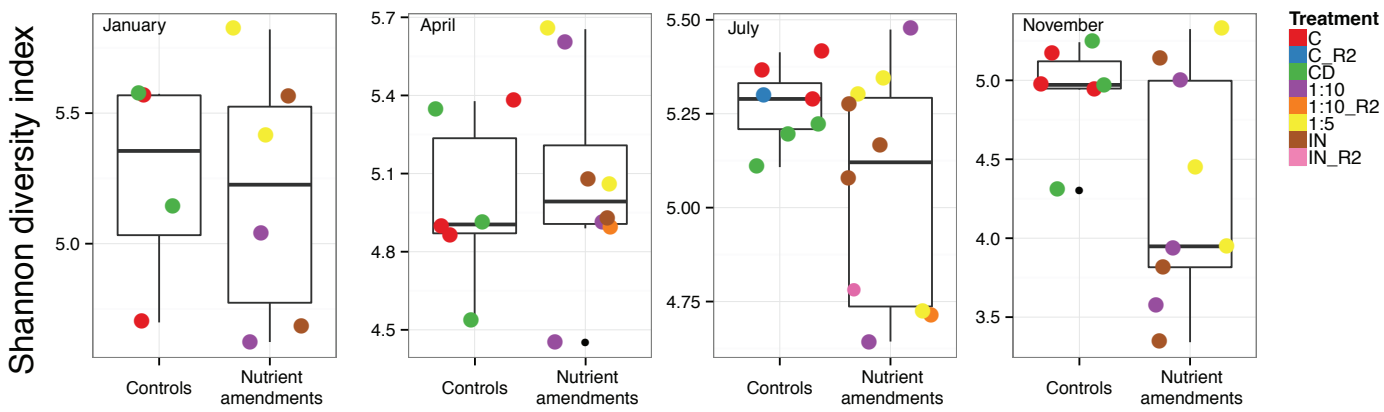

Figure 7. Differences in alpha-diversity, estimated from the Shannon index, between controls and nutrient amendment - i.e. all nutrientamended treatments were binned and compared against all controls. Circles denote variation in alpha-diversity within the binned samples. Colours correspond to different treatments.

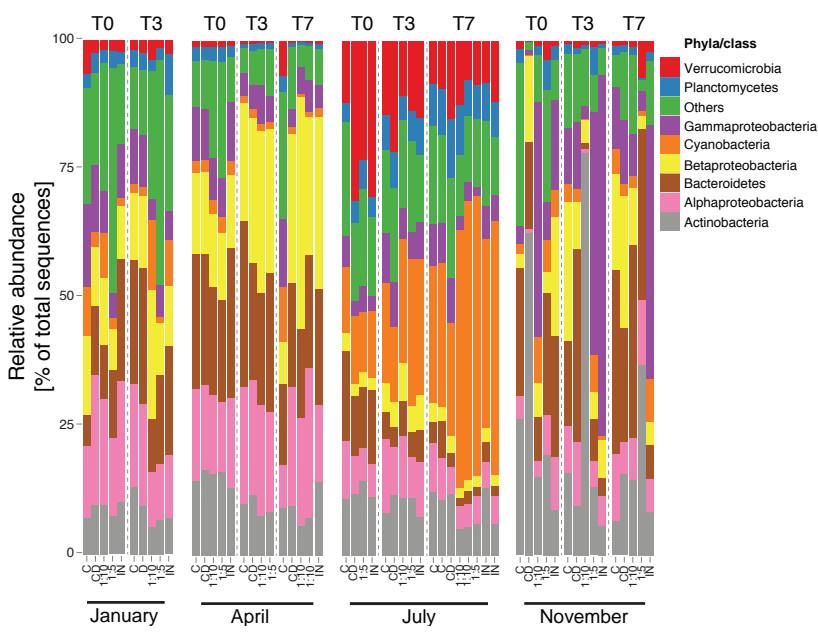

Figure 8. Relative abundances (i.e. percentage of total sequences) of major bacterial groups at phyla/class level in the different treatments and experiments. Colours denote specific groups.

proteobacterial OTU affiliated with Rhodobacteraceae (OTU 000044) exhibited strong correlations with metabolic activities and environmental variables, both negative (e.g. $\mathrm{PO}_{4}^{3-}$ and community respiration) and positive (e.g. temperature and bacterial production). Moreover, 10 Rhodobacteraceae OTUs were positively correlated with DOC. Synechococcus OTUs were positively correlated with temperature, NCP, GPP, bacterial production and Chl $a$ (Fig. S3).

To extend the analysis of the strong Cyanobacteria population dynamics observed in the July experiment, we investigated particular OTUs and plotted relative abundances of this group across all experiments (Fig. S4). For the other experiments, cyanobacterial populations had, in general, low relative abundance but were still more abundant in treatments with effluent and nutrients amendments than without (except for the April experiment). Six OTUs showed particularly high relative abundance in the July experiment (Fig. S4). These cyanobacterial populations increased with time and at T7 both Synechococcus and Cyanobium populations had higher relative abundance in treatments of $1: 10,1: 5$ and IN compared to controls.

\section{Discussion}

Nitrogen-rich dissolved organic matter (DOM) from WWTP effluents had significant impacts on Baltic Sea planktonic metabolic rates: DOM significantly increased bacterial production, whereas it decreased gross and net primary production and community respiration rates, as showed in the results of the mixed-effects models, where DOC is used as a proxy for DOM. Bacterial production was also positively correlated with DON concentration, suggesting that DON can provide nitrogen nutrition to bacteria. BP was negatively correlated with phosphate concentration, due to seasonal variations, as phosphate content is higher in winter when BP is low. A parallel increase in BP and decrease in bacterial respiration (BR) rates results in an increase in bacterial growth efficiency $(\mathrm{BGE}=(\mathrm{BP}) /(\mathrm{BP}+\mathrm{BR})$; del Giorgio and Cole, 1998). Literature values for BGE in the Baltic Sea vary substantially from 0.06 to 0.6 (Donali et al., 1999). Here we did not measure bacterial respiration separately, but as a part of total community respiration. Assuming that bacterial respiration contributes $50 \%$ of community respiration (Williams, 1981; Aranguren-Gassis et al., 2012), we can estimate BGE. As BR is known to be higher than $50 \%$ of CR (Williams, 1981), this approach will result in an underestimation of bacterial growth efficiency but will suffice to support our hypothesis that DOM additions increased BGE. Estimated BGE for our experiments varied between 0.06 and 0.59 , consistent with previous reported values (Donali et al., 1999; Zweifel et al., 1993). Estimated BGE increased with nitrate $(p<0.003)$ and DOC concentration $(p<0.0007)$ and decreased with phosphate content $(p<0.02$, mixed-effects model, $R^{2}=0.78$ ). An increase in BGE with nutrient addition was reported for communities from the Bothnian Bay, increasing from a range of $0.11-0.54$ to $0.14-0.58$ for treatments with nutrient amendment (Zweifel et al., 1993). Other studies also report an increase in BGE with DOM and nutri- 
ent additions in three estuaries from the Baltic Sea (Asmala et al., 2013). Our estimation of BGE shows a positive effect of $\mathrm{N}$-rich DOM on bacterial growth efficiency, suggesting high lability of N-rich WWTP effluent DOM, where most of the carbon can be used for secondary bacterial production and a low portion is respired.

Wastewater treatment plant effluent inputs to the Baltic Sea raised bacterial production at the same time as it reduced primary production, leading to more carbon being used by the microbial loop. This increase in bacterial production parallel with a decrease in primary production moves the ecosystem towards heterotrophy. This is supported by a higher BP : NCP ratio in treatments with addition of WWTP effluent (mean $=1.56 \pm 0.38$ ), compared to treatments without amendment (mean $=0.66 \pm 0.32$ ), although these differences are not significant $(p>0.05)$. Increased flow of organic matter through the microbial loop could result in a reduction in the transfer of carbon to higher trophic levels and of the efficiency of the biological carbon pump in sequestering carbon (Berglund et al., 2007; Wohlers et al., 2009). Bacteria-based food webs generally have lower food web efficiency due to the smaller sizes of the resources and predators, leading to more trophic levels than phytoplankton-based food webs. As around $70 \%$ of ingested carbon is lost at each trophic level due to respiration and sloppy feeding (Straile, 1997), larger carbon losses are expected in bacteria-based food webs (Berglund et al., 2007). Whereas some studies suggest that an increased flow of carbon through the microbial loop would result in a reduction in biological carbon pump efficiency in sequestering carbon, a recent study suggests the opposite: marine bacteria can produce refractory exometabolites that would result in carbon sequestration (Lechtenfeld et al., 2015).

Effluent inputs decreased GPP and NCP, resulting in a reduction in photosynthetic rates, declining oxygen production in the photic layer. The Baltic Sea is already the largest eutrophication-driven hypoxic area in the world (Conley et al., 2011), and a decrease in biological oxygen production could further aggravate hypoxic conditions in this already affected area. The lack of oxygen is an important environmental problem is this area; it produces a reduction in marine benthic diversity as a result of the death of sensitive marine organisms and it affects biogeochemical cycles (Conley et al., 2009). Furthermore, it increases phosphorus fluxes from sediments into overlaying waters, changing redox conditions in the water column and reduces the ecosystem capacity of removing nitrogen, as a consequence of the reduction in the substrate needed for denitrification (nitrate) when sediments become more reducing (Conley et al., 2009).

Although several microbial taxa showed weak correlations with contemporary changes in environmental conditions and/or metabolic activity, specific opportunistic populations proliferated in effluent input treatments. In particular, verrucomicrobial and cyanobacterial populations responded in relative abundance to effluent inputs in summer. Thus,

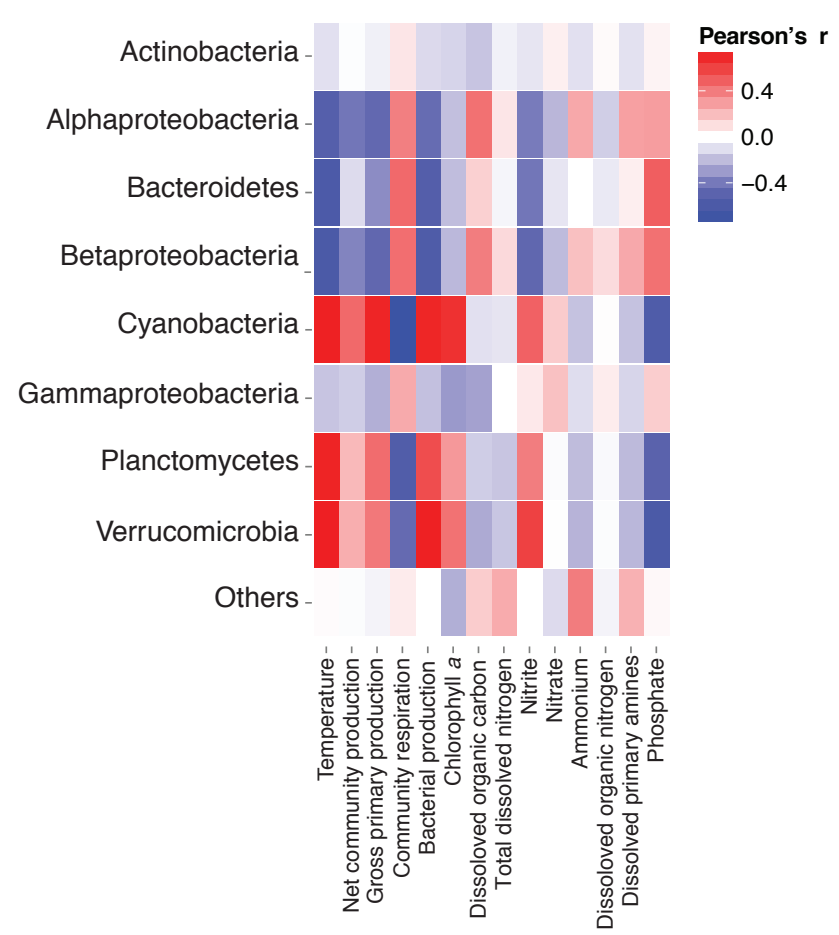

Figure 9. Correlations between shifts in relative abundances of major bacterial groups at phyla/class level and environmental factors and metabolic activity. The level of correlation is estimated from Pearson's $r$, where blue and red indicate negative and positive correlations, respectively.

OTUs affiliated with Verrucomicrobia decreased in relative abundance in the treatments with effluent addition compared to controls. In contrast, the relative abundance of a few specific cyanobacterial populations increased upon enrichment (but less so in controls - i.e. the cyanobacterial growth was not only an effect of higher temperatures in the summer experiment). Generally, it is likely that the proliferation of cyanobacteria in the summer experiment is linked to the actual abundance of cyanobacteria, which is typically higher in summer, so that the "seeding" population for this taxon was higher. The Baltic Sea suffers from extensive Cyanobacteria blooms in summer that can easily be observed from space, primarily caused by eutrophication (Vahtera et al., 2007). The death and sedimentation of Cyanobacteria blooms, and the subsequent decay of this organic material, is a contributing mechanism for oxygen depletion in bottom waters. Consequently, Cyanobacteria blooms have been linked to hypoxia development and expansion in the Baltic Sea. Warming could further increase cyanobacteria blooms in the Baltic Sea (Paerl and Huisman, 2008; Paerl and Paul, 2012). Here, we found that relative abundances of Cyanobacteria were positively correlated with temperature.

Links between metabolic activity and compositional changes of bacterial communities are frequently observed in aquatic ecosystems (Bell et al., 2005; Allison and Martiny, 
2008; Logue et al., 2016). Yet, in other cases, such linkages are relatively weak and possibly confounded by environmental complexity (Comte and Del Giorgio, 2011; Comte et al., 2013; Langenheder et al., 2005, 2010). Our results showed that effluent inputs caused simultaneous shifts in community composition coupled with changes in metabolic rates. Changes in temperature were the major driver of community structure, but phosphate also significantly explained variations in the relative abundance of particular groups and taxa. This emphasises that changes in temperature and nutrient availability can affect bacterioplankton community dynamics. Similarly, differences in temperature and nutrient conditions lead to shifts in community structure in, for example, mesocosm experiments with Mediterranean and Baltic Sea microbial assemblages (Degerman et al., 2013; GomezConsarnau et al., 2012; Pinhassi et al., 2006; von Scheibner et al., 2014). More importantly, in these studies, compositional shifts occurred with concomitant responses in community metabolic activity. Apart from the influence of temperature in structuring the bacterial communities in the present study, shifts in bacterioplankton community composition were highly correlated with changes in phosphate concentrations. In agreement, previous findings show that phosphate is a driver of shifts in community structure in the southern Californian coast and Baltic Sea (Fuhrman et al., 2006; Andersson et al., 2010). For example, Andersson et al. (2010) suggested that limiting conditions due to a decline in phosphate during the summer Cyanobacterial bloom promote selection in the bacterioplankton community where specific OTUs can proliferate. Moreover, in an adjacent area of the Baltic Sea Proper, opportunistic cyanobacteria, including $\mathrm{N}_{2}$-fixers and picocyanobacteria, proliferated despite low phosphorus concentrations and may instead have been fuelled by bioavailable nutrients from filamentous Cyanobacteria (Bertos-Fortis et al., 2016). Recent evidence suggests that availability of phosphorus has a substantial impact on eutrophication in the Baltic Sea since many Cyanobacteria are able to fix nitrogen (Andersson et al., 2015). In the present study, phosphate concentrations showed small variations between treatments within each experiment and we observed primarily seasonal oscillations between experiments. Absolute shifts in composition among the groups Bacteroidetes, Betaproteobacteria and Alphaproteobacteria were positively correlated with absolute changes in phosphate, whereas shifts in Planctomycetes, Verrucomicrobia and Cyanobacteria were negatively correlated with variation in phosphate. Nevertheless, changes in phosphate concentrations significantly explained variation in community structure within the July experiment. Hence, the communities responded to effluent inputs by shifts in species composition and the influence of seasonal changes in phosphorus concentrations was outweighed by the simulated environmental disturbance investigated here. Thus, long-term changes in phosphorus resulting from natural seasonal variation or climatechange-related effects accompanied by episodic short-term effluent inputs may form a synergistic permanent impact on the structure of bacterioplankton communities with severe consequences for ecosystem services. In agreement, shifts in community composition can be closely linked with changes in community functioning, i.e. metabolic rates (e.g. Bell et al., 2005; Allison and Martiny, 2008). In addition, alphadiversity was lower in effluent input treatments. The observed effect of species loss, i.e. lower richness (observed number of OTUs and Chao.1 index) and the Shannon diversity index, may be closely linked with the functioning of microbial communities and could potentially render the whole community more sensitive to environmental perturbations (Allison and Martiny, 2008; Bell et al., 2005; Loreau, 2000, 2004; Shade et al., 2012). Alternatively, lower richness and Shannon diversity index does not necessarily imply loss of community functioning as previously observed in, for example, lake systems (Comte and del Giorgio, 2011; Langenheder et al., 2005). Hence, our findings suggest that linked alterations in bacterial community composition and metabolic activity from anthropogenic changes could potentially affect biogeochemical cycling of elements in the coastal Baltic Sea.

The so-called "bottle effect", in which confinement of water causes shifts in bacterioplankton community composition and physiological rates, is a factor to consider in interpreting results from experiments with natural microbial assemblages (Fuchs et al., 2000; Massana et al., 2001; Baltar et al., 2012). Such effects are typically detected by rapidly increasing proportions of fast-growing gammaproteobacterial populations and rate measurements across all treatments (including controls; Pinhassi and Berman, 2003; Sjöstedt et al., 2012; Dinasquet et al., 2013). In our current experiments, microbial community composition remained relatively similar to in situ communities and we did not observe excessive increases in opportunistic bacterial populations in the controls. Rather, increases and decreases in relative abundance were observed among populations typical of Baltic Sea Proper, such as Rhodobacteraceae, Synechococcus and BAL58 (Lindh et al., 2015). Thus, although confinement per se surely had effects on microbial diversity and rates, our results indicate that such effects were minor relative to the actual treatment effects.

Inputs of WWTP effluent further stimulated bacterial production in summer, when it was already high due to elevated temperatures. Summer was the period of the year that responded sharply to effluent additions. Warming could also increase respiration rates to a larger degree than primary production, moving the system towards heterotrophy (Brown et al., 2004; Harris et al., 2006; Vaquer-Sunyer et al., 2015; Yvon-Durocher et al., 2010). Simultaneous warming and inputs from wastewater treatment plant effluents increased planktonic respiration rates and bacterial production faster than it increased planktonic primary production in the Baltic Sea (Vaquer-Sunyer et al., 2015), leading to higher biological oxygen consumption than production, which may lead to the depletion of the oxygen pool, further aggravating hy- 
poxia in the Baltic Sea. Here, we found that WWTP effluent inputs increased bacterial production at the same time as they decreased net and gross primary production and community respiration. A parallel increase in bacterial production and decrease in primary production leads to more carbon being used by the microbial loop and may have consequences for food web transfer efficiency.

\section{Conclusions}

The current study showed that inputs of DOM from WWTP effluents were related to increased bacterial production and decreased primary production and community respiration, which could lead to an increase in BGE. DON concentration enhanced bacterial production, suggesting that bacteria can use DON as a nitrogen source. The increase in BP and decrease in CR could be caused by high lability of the OM that supported secondary bacterial production, without an increase in respiration. Seasonal changes in temperature were the most important factor for structuring community composition, but phosphate concentrations also significantly explained variations in the relative abundance of particular groups and taxa. In summer, the relative abundance of Cyanobacteria increased after effluent inputs (but less so in the controls). Cyanobacteria have been linked to hypoxia in the Baltic Sea, and an increase in their abundance could result in oxygen depletion of the Baltic bottom waters. Inputs from wastewater treatment plant effluent could further worsen hypoxic conditions in the Baltic Sea.

Reductions in the OM content in wastewater treatment plant effluents are needed to reduce its potential negative consequences. Effluent inputs resulted in a reduction in photosynthetic rates, moving the system towards heterotrophy, decreasing oxygen production in the photic layer in the Baltic Sea.

\section{Data availability}

STRÅNG data used here are from the Swedish Meteorological and Hydrological Institute (SMHI), and were produced with support from the Swedish Radiation Protection Authority and the Swedish Environmental Agency.

\section{The Supplement related to this article is available online at doi:10.5194/bg-13-4751-2016-supplement.}

Author contributions. Raquel Vaquer-Sunyer designed research and performed experiments. Markus V. Lindh, Jarone Pinhassi and Saraladevi Muthusamy analysed bacterial diversity samples and data. Heather E. Reader wrote the code for metabolic rates calculations. All authors were involved in the writing stage of the manuscript and collaborated on the analysis, interpretation, and discussion of the results.

Acknowledgements. The authors would like to thank Catherine Legrand, Emil Fridolfsson, Anders Månsson and Kristofer Bergström at the Linnaeus University for their help on Kalmar's WWTP effluent water and seawater sampling. We would also like to thank Carolina Funkey for help with nutrient analysis and Elena Baraza for statistical advice. Raquel VaquerSunyer was supported by a Marie Curie Intra-European Fellowship (IEF). This research is a contribution to the projects "The role of dissolved organic nitrogen (DON) on the development and extent of eutrophication-driven hypoxia and responses to global warming", funded by the FP7 Marie Curie IEF (grant number 299382), and "Managing multiple stressors in the Baltic Sea", funded by FORMAS (grant number 217-2010-126). This work resulted from the BONUS COCOA project and the BONUS BLUEPRINT project, which were supported by BONUS (Art 185), funded jointly by the EU and the Swedish Research Council FORMAS.

Edited by: G. Herndl

Reviewed by: three anonymous referees

\section{References}

Allison, S. D. and Martiny, J. B.: Resistance, resilience, and redundancy in microbial communities, P. Natl. Acad. Sci. USA, 105, 11512-11519, doi:10.1073/pnas.0801925105, 2008.

Andersson, A., Hoglander, H., Karlsson, C., and Huseby, S.: Key role of phosphorus and nitrogen in regulating cyanobacterial community composition in the northern Baltic Sea, Estuar. Coast. Shelf S., 164, 161-171, doi:10.1016/j.ecss.2015.07.013, 2015.

Andersson, A. F., Riemann, L., and Bertilsson, S.: Pyrosequencing reveals contrasting seasonal dynamics of taxa within Baltic Sea bacterioplankton communities, Isme J., 4, 171-181, doi:10.1038/ismej.2009.108, 2010.

Aranguren-Gassis, M., Teira, E., Serret, P., Martinez-Garcia, S., and Fernandez, E.: Potential overestimation of bacterial respiration rates in oligotrophic plankton communities, Mar. Ecol.Prog. Ser., 453, 1-10, doi:10.3354/meps09707, 2012.

Asmala, E., Autio, R., Kaartokallio, H., Pitkänen, L., Stedmon, C. A., and Thomas, D. N.: Bioavailability of riverine dissolved organic matter in three Baltic Sea estuaries and the effect of catchment land use, Biogeosciences, 10, 6969-6986, doi:10.5194/bg10-6969-2013, 2013.

Baltar, F., Lindh, M. V., Parparov, A., Berman, T., and Pinhassi, J.: Prokaryotic community structure and respiration during long-term incubations, Microbiology Open, 1, 214-224, doi:10.1002/mbo3.25, 2012.

Bell, T., Newman, J. A., Silverman, B. W., Turner, S. L., and Lilley, A. K.: The contribution of species richness and composition to bacterial services, Nature, 436, 1157-1160, 2005.

Berglund, J., Muren, U., Bamstedt, U., and Andersson, A.: Efficiency of a phytoplankton-based and a bacteria-based food web 
in a pelagic marine system, Limnol. Oceanogr., 52, 121-131, 2007.

Berman, T. and Bronk, D. A.: Dissolved organic nitrogen: a dynamic participant in aquatic ecosystems, Aquat. Microb. Ecol., 31, 279-305, 2003.

Bertos-Fortis, M., Farnelid, H. M., Lindh, M. V., Casini, M., Andersson, A., Pinhassi, J., and Legrand, C.: Unscrambling cyanobacteria community dynamics related to environmental factors, Front. Microbiol., 7, 625, doi:10.3389/fmicb.2016.00625, 2016.

Bronk, D. A., Lomas, M. W., Glibert, P. M., Schukert, K. J., and Sanderson, M. P.: Total dissolved nitrogen analysis: comparisons between the persulfate, UV and high temperature oxidation methods, Mar. Chem., 69, 163-178, 2000.

Bronk, D. A., Roberts, Q. N., Sanderson, M. P., Canuel, E. A., Hatcher, P. G., Mesfioui, R., Filippino, K. C., Mulholland, M. R., and Love, N. G.: Effluent Organic Nitrogen (EON): Bioavailability and Photochemical and Salinity-Mediated Release, Environ. Sci. Technol., 44, 5830-5835, 2010.

Brown, J. H., Gillooly, J. F., Allen, A. P., Savage, V. M., and West, G. B.: Toward a metabolic theory of ecology, Ecology, 85, 17711789, 2004

Carstensen, J., Andersen, J. H., Gustafsson, B. G., and Conley, D. J.: Deoxygenation of the Baltic Sea during the last century, P. Natl. Acad. Sci. USA, 111, 5628-5633, 2014.

Cole, J. J., Pace, M. L., Carpenter, S. R., and Kitchell, J. F.: Persistence of net heterotrophy in lakes during nutrient addition and food web manipulations, Limnol. Oceanogr., 45, 1718-1730, 2000.

Comte, J. and Del Giorgio, P. A.: Composition influences the pathway but not the outcome of the metabolic response of bacterioplankton to resource shifts, PLoS One, 6, e25266, doi:10.1371/journal.pone.0025266, 2011

Comte, J., Fauteux, L., and del Giorgio, P. A.: Links between metabolic plasticity and functional redundancy in freshwater bacterioplankton communities, Front. Microbiol., 4, 112, doi:10.3389/fmicb.2013.00112, 2013.

Conley, D. J., Carstensen, J., Vaquer-Sunyer, R., and Duarte, C. M.: Ecosystem thresholds with hypoxia, Hydrobiologia, 629, 21-29, 2009.

Conley, D. J., Carstensen, J., Aigars, J., Axe, P., Bonsdorff, E., Eremina, T., Haahti, B. M., Humborg, C., Jonsson, P., Kotta, J., Lännegren, C., Larsson, U., Maximov, A., Rodriguez Medina, M., Lysiak-Pastuszak, E., Remeikaite-Nikiene, N., Walve, J., Wilhelms, S., and Zillén, L.: Hypoxia is increasing in the coastal zone of the Baltic Sea, Environ. Sci. Technol., 5, 6777-6783, doi:10.1021/es201212r, 2011.

Degerman, R., Dinasquet, J., Riemann, L., de Luna, S. S., and Andersson, A.: Effect of resource availability on bacterial community responses to increased temperature, Aquat. Microb. Ecol., 68, 131-142, doi:10.3354/ame01609, 2013.

del Giorgio, P. A. and Cole, J. J.: Bacterial growth efficiency in natural aquatic systems, Annu. Rev. Ecol. Syst., 29, 503-541, doi:10.1146/annurev.ecolsys.29.1.503, 1998.

Dinasquet, J., Kragh, T., Schroter, M. L., Sondergaard, M., and Riemann, L.: Functional and compositional succession of bacterioplankton in response to a gradient in bioavailable dissolved organic carbon, Environ. Microbiol., 15, 2616-2628, doi:10.1111/1462-2920.12178, 2013.
Donali, E., Olli, K., Heiskanen, A. S., and Andersen, T.: Carbon flow patterns in the planktonic food web of the Gulf of Riga, the Baltic Sea: a reconstruction by the inverse method, J. Marine Syst., 23, 251-268, 10.1016/s0924-7963(99)00061-5, 1999.

Edgar, R. C.: UPARSE: highly accurate OTU sequences from microbial amplicon reads, Nat. Methods, 10, 996-998, doi:10.1038/nmeth.2604, 2013.

Fleming-Lehtinen, V., Andersen, J. H., Carstensen, J., LysiakPastuszak, E., Murray, C., Pyhälä, M., and Laamanen, M.: Recent developments in assessment methodology reveal that theBaltic Sea eutrophication problem is expanding, Ecol. Indic., 48 , 380-388, 2015.

Fuchs, B. M., Zubkov, M. V., Sahm, K., Burkill, P. H., and Amann, R.: Changes in community composition during dilution cultures of marine bacterioplankton as assessed by flow cytometry and molecular biology techniques, Environ. Microbiol., 2, 191-201, 2000.

Fuhrman, J. A., Hewson, I., Schwalbach, M. S., Steele, J. A., Brown, M. V., and Naeem, S.: Annually reoccurring bacterial communities are predictable from ocean conditions, P. Natl. Acad. Sci. USA, 103, 13104-13109, doi:10.1073/pnas.0602399103, 2006.

Gomez-Consarnau, L., Lindh, M. V., Gasol, J. M., and Pinhassi, J.: Structuring of bacterioplankton communities by specific dissolved organic carbon compounds, Environ. Microbiol., 14, 2361-2378, doi:10.1111/j.1462-2920.2012.02804.x, 2012.

Grady, C. P. L., Daigger, G. T., Love, N. G., and Filippe, C. D. M.: Biological Wastewater Treatment, 3rd ed., Environmental Science and Pollution Series 19, CRC Press, 991 pp., 2011.

Grande, K. D., Marra, J., Langdon, C., Heinemann, K., and Bender, M. L.: Rates of Respiration in the Light Measured in MarinePhytoplankton Using an O-18 Isotope-Labeling Technique, J. Exp. Mar. Biol. Ecol., 129, 95-120, 1989.

Harris, L. A., Duarte, C. M., and Nixon, S. W.: Allormetric laws and prediction in estuarine and coastal ecology, Estuar. Coast., 29, 340-344, 2006.

Hautakangas, S., Ollikainen, M., Aarnos, K., and Rantanen, P.: Nutrient Abatement Potential and Abatement Costs of Waste Water Treatment Plants in the Baltic Sea Region, Ambio, 43, 352-360, doi:10.1007/s13280-013-0435-1, 2014.

Herlemann, D. P. R., Labrenz, M., Jurgens, K., Bertilsson, S., Waniek, J. J., and Andersson, A. F.: Transitions in bacterial communities along the $2000 \mathrm{~km}$ salinity gradient of the Baltic Sea, ISME J., 5, 1571-1759, 2011.

Hugerth, L. W., Muller, E. E. L., Hu, Y. O. O., Lebrun, L. A. M., Roume, H., Lundin, D., Wilmes, P., and Andersson, A. F.: Systematic design of $18 \mathrm{~S}$ rRNA gene primers for determining Eukaryotic diversity in microbial consortia, PLoS One, 9, e95567, doi:10.1371/journal.pone.0095567, 2014.

Jespersen, A. M. and Christoffersen, K.: Measurements of chlorophyll-a from phytoplankton using ethanol as extraction solvent, Archiv fur Hydrobiologie, 109, 445-454, 1987.

Kirchman, D. L.: Measuring bacterial biomass production and growth rates from leucine incorporation in natural aquatic environments, in: Methods in microbiology, edited by: Paul, J. H., Academic Press, London, 227-237, 2001.

Koroleff, F.: Determination of nutrients, in: Methods of Seawater Analysis, edited by: Grasshoff, K., Ehrhardt, M., and Kremling, K., Verlag Chemie, Weinheim, Germany, 150-157, 1983. 
Langenheder, S., Lindstrom, E. S., and Tranvik, L. J.: Weak coupling between community composition and functioning of aquatic bacteria, Limnol. Oceanogr., 50, 957-967, 2005.

Langenheder, S., Bulling, M. T., Solan, M., and Prosser, J. I.: Bacterial Biodiversity-Ecosystem Functioning Relations Are Modified by Environmental Complexity, PLoS One, 5, e10834, doi:10.1371/journal.pone.0010834, 2010.

Lechtenfeld, O. J., Hertkorn, N., Shen, Y., Witt, M., and Benner, R.: Marine sequestration of carbon in bacterial metabolites, Nat. Commun., 6, 6711, doi:10.1038/ncomms7711, 2015.

Lindh, M. V., Sjöstedt, J., Andersson, A. F., Baltar, F., Hugerth, L. W., Lundin, D., Muthusamy, S., Legrand, C., and Pinhassi, J.: Disentangling seasonal bacterioplankton population dynamics by high-frequency sampling, Environ. Microbiol., 17, 24592476, doi:10.1111/1462-2920.12720, 2015.

Logue, J. B., Stedmon, C. A., Kellerman, A. M., Nielsen, N. J., Andersson, A. F., Laudon, H., Lindstrom, E. S., and Kritzberg, E. S.: Experimental insights into the importance of aquatic bacterial community composition to the degradation of dissolved organic matter, ISME J., 10, 533-545, doi:10.1038/ismej.2015.131, 2016.

Loreau, M.: Biodiversity and ecosystem functioning: recent theoretical advances, Oikos, 91, 3-17, doi:10.1034/j.16000706.2000.910101.x, 2000.

Loreau, M.: Does functional redundancy exist?, Oikos, 104, 606611, doi:10.1111/j.0030-1299.2004.12685.x, 2004.

Massana, R., Pedros-Alio, C., Casamayor, E. O., and Gasol, J. M.: Changes in marine bacterioplankton phylogenetic composition during incubations designed to measure biogeochemically significant parameters, Limnol. Oceanogr., 46, 1181-1188, 2001.

Oksanen, J., Kindt, R., Legendre, P., O’Hara, B., Stevens, M. H. H., Oksanen, M. J., and Suggests, M.: The vegan package, Community Ecology Package, 10, 2007.

Pace, M. L. and Prairie, Y. T.: Respiration in lakes, in: És un llibre, edited by: del Giorgio, P. A. and Williams, P. J. B., Oxford University Press, Oxford, 103-121, 2005.

Paerl, H. W. and Huisman, J.: Climate - Blooms like it hot, Science, 320, 57-58, doi:10.1126/science.1155398, 2008.

Paerl, H. W. and Paul, V. J.: Climate change: Links to global expansion of harmful cyanobacteria, Water Res., 46, 1349-1363, doi:10.1016/j.watres.2011.08.002, 2012.

Parsons, T. R., Maita, Y., and Lalli, C. M.: A manual of chemical and biological methods for seawater analysis, Deep-Sea Res, Pergamon Press, Oxford, 173 pp., 1984.

Pinhassi, J. and Berman, T.: Differential growth response of colonyforming alpha- and gamma-proteobacteria in dilution culture and nutrient addition experiments from Lake Kinneret (Israel), the eastern Mediterranean Sea, and the Gulf of Eilat, Appl. Environ. Microbiol., 69, 199-211, doi:10.1128/Aem.69.1.199-211.2003, 2003.

Pinhassi, J., Gomez-Consarnau, L., Alonso-Saez, L., Sala, M. M., Vidal, M., Pedros-Alio, C., and Gasol, J. M.: Seasonal changes in bacterioplankton nutrient limitation and their effects on bacterial community composition in the NW Mediterranean Sea, Aquat. Microb. Ecol., 44, 241-252, 2006.

Pringault, O., Tassas, V., and Rochelle-Newall, E.: Consequences of respiration in the light on the determination of production in pelagic systems, Biogeosciences, 4, 105-114, doi:10.5194/bg-4105-2007, 2007.
Quast, C., Pruesse, E., Yilmaz, P., Gerken, J., Schweer, T., Yarza, P., Peplies, J., and Glöckner, F. O.: The SILVA ribosomal RNA gene database project: improved data processing and web-based tools, Nucleic Acids Res, 41, D590-D596, 2013.

Seitzinger, S. P., Harrison, J. A., Dumont, E., Beusen, A. H. W., and Bouwman, A. F.: Sources and delivery of carbon, nitrogen, and phosphorus to the coastal zone: An overview of Global Nutrient Export from Watersheds (NEWS) models and their application, Global Biogeochem. Cy., 19, GB4S01, doi:10.1029/2005GB002606, 2005

Shade, A., Peter, H., Allison, S. D., Baho, D. L., Berga, M., Buergmann, H., Huber, D. H., Langenheder, S., Lennon, J. T., Martiny, J. B. H., Matulich, K. L., Schmidt, T. M., and Handelsman, J.: Fundamentals of microbial community resistance and resilience, Front. Microbiol., 3, 417, doi:10.3389/fmicb.2012.00417, 2012.

Sjostedt, J., Koch-Schmidt, P., Pontarp, M., Canback, B., Tunlid, A., Lundberg, P., Hagstrom, A., and Riemann, L.: Recruitment of members from the rare biosphere of marine bacterioplankton communities after an environmental disturbance, Appl. Environ Microbiol., 78, 1361-1369, 2012.

Smith, D. C. and Azam, F.: A simple, economical method for measuring bacterial protein synthesis rates in seawater using $3 \mathrm{H}-$ leucine, Marine Microbial Food Webs, 6, 107-111, 1992.

Sondergaard, M., Stedmon, C. A., and Borch, N. H.: Fate of terrigenous dissolved organic matter (DOM) in estuaries: Aggregation and bioavailability, Ophelia, 57, 161-176, 2003.

Straile, D.: Gross growth efficiencies of protozoan and metazoan zooplankton and their dependence on food concentration, predator-prey weight ratio, and taxonomic group, Limnol. Oceanogr., 42, 1375-1385, 1997.

Strång Model, Swedish meteorological and hydrological institute (SMHI): http://strang.smhi.se/extraction/index.php?data= tmsrs\&lev=2, last access: 15 June 2016.

Tamura, K., Peterson, D., Peterson, N., Stecher, G., Nei, M., and Kumar, S.: MEGA5: Molecular Evolutionary Genetics Analysis Using Maximum Likelihood, Evolutionary Distance, and Maximum Parsimony Methods, Mol. Biol. Evol., 28, 2731-2739, doi:10.1093/Molbev/Msr121, 2011.

Vahtera, E., Conley, D. J., Gustafsson, B. G., Kuosa, H., Pitkanen, H., Savchuk, O. P., Tamminen, T., Viitasalo, M., Voss, M., Wasmund, N., and Wulff, F.: Internal ecosystem feedbacks enhance nitrogen-fixing cyanobacteria blooms and complicate management in the Baltic Sea, Ambio, 36, 186-194, doi:10.1579/00447447(2007)36[186:iefenc]2.0.co;2, 2007.

Vaquer-Sunyer, R. and Duarte, C. M.: Thresholds of hypoxia for marine biodiversity, P. Natl. Acad. Sci. USA., 105, 15452 15457, 2008.

Vaquer-Sunyer, R., Conley, D. J., Muthusamy, S., Lindh, M. V., Pinhassi, J., and Kritzberg, E. S.: Dissolved Organic Nitrogen Inputs from Wastewater Treatment Plant Effluents Increase Responses of Planktonic Metabolic Rates to Warming, Environ. Sci. Technol., 49, 11411-11420, doi:10.1021/acs.est.5b00674, 2015.

von Scheibner, M., Dörge, P., Biermann, A., Sommer, U., Hoppe, H.-G., and Jürgens, K.: Impact of warming on phytobacterioplankton coupling and bacterial community composition in experimental mesocosms, Environ. Microbiol., 16, 718-733, doi:10.1111/1462-2920.12195, 2014. 
Wickham, H.: ggplot2: elegant graphics for data analysis, Springer, New York, 2009.

Williams, P. J. L.: Microbial contribution to overall marine plankton metabolism: direct measurements of respiration, Oceanol. Acta, 4, 359-364, 1981.

Wohlers, J., Engel, A., Zöllner, E., Breithaupt, P., Jurgens, K., Hoppe, H. G., Sommer, U., and Riebesell, U.: Changes in biogenic carbon flow in response to sea surface warming, P. Natl. Acad. Sci. USA, 106, 7067-7072, 2009.

Wright, J. J., Konwar, K. M., and Hallam, S. J.: Microbial ecology of expanding oxygen minimum zones, Nature Rev. Microbiol., 10, 381-394, doi:10.1038/nrmicro2778, 2012.
$\mathrm{Xu}$, R. H.: Measuring explained variation in linear mixed effects models, Statistics in Medicine, 22, 3527-3541, doi:10.1002/sim.1572, 2003.

Yvon-Durocher, G., Jones, J. I., Trimmer, M., Woodward, G., and Montoya, J. M.: Warming alters the metabolic balance of ecosystems, Philos. T. R. Soc. B, 365, 2117-2126, 2010.

Zweifel, U. L., Norrman, B., and Hagstrom, A.: Consumption of dissolved organic-carbon by marine-bacteria and demand for inorganic nutrients, Mar. Ecol.-Prog. Ser., 101, 23-32, doi:10.3354/meps101023, 1993. 